\title{
Risk factors for childhood pneumonia: a case-control study in a high prevalence area in Indonesia
}

\author{
Vivi Ninda Sutriana, $\mathrm{MPH}^{1}$, Mei Neni Sitaresmi, MD, $\mathrm{PhD}^{2}, \mathrm{Abdul}$ Wahab, $\mathrm{Dr}, \mathrm{MPH}^{3}$ \\ ${ }^{1}$ Master in Public Health Sciences Faculty of Medicine, Public Health and Nursing Universitas Gadjah Mada, Yogyakarta, Indonesia; ${ }^{2}$ Department of Child Health, \\ Faculty of Medicine, Public Health and Nursing Universitas Gadjah Mada, Yogyakarta, Indonesia; ${ }^{3}$ Dapertment of Biostatistics, Epidemiology and Population Health \\ Faculty of Medicine, Public Health and Nursing Universitas Gadjah Mada, Yogyakarta, Indonesia
}

\begin{abstract}
Background: Acute respiratory infections (ARIs), especially pneumonia, remain a major cause of infant mortality worldwide. In Indonesia, pneumonia is the second most common cause of infant and toddler deaths. Exclusive breastfeeding and basic immunization can protect infants and children from contracting pneumonia.
\end{abstract}

Purpose: Our goal was to assess the risk factors for childhood pneumonia in regions with a high prevalence of pneumonia in Indonesia.

Methods: This case-control study was conducted between March and April 2019. A total of 176 infants and toddlers aged 10-59 months were enrolled and selected from among patients who visited the community health center. Cases of pneumonia were diagnosed clinically based on the World Health Organization guidelines, and the control was nonpneumonia.

Results: The risk factors for the diagnosis of pneumonia included no or nonexclusive breastfeeding (odds ratio [OR], 7.95; 95\% confidence interval [CI], 3.52-17.94), incomplete basic immunizations (OR, 4.47; 95\% CI, 2.22-8.99), indoor air pollution (OR, 7.12; 95\% CI, 3.03-16.70), low birth weight (OR, 3.27; 95\% CI, 1.19-8.92), and a high degree of wasting (OR, 2.77; 95\% CI, 1.06-7.17). Other variables such as nutritional status (height-for-age $z$ score), age, sex, and educational status of the mother were not risk factors for pneumonia.

Conclusion: No or nonexclusive breastfeeding, incomplete basic immunizations, indoor air pollution, a history of low birth weight, and severe malnutrition were risk factors for childhood pneumonia. Breastfeeding was the dominant factor, while sex modified the relationship between exclusive breastfeeding and the incidence of pneumonia.

Key words: Pneumonia, Respiratory tract infections, Breast feeding, Immunization, Nutritional status

\section{Key message}

Question: Is the incidence of childhood pneumonia influenced by breastfeeding and basic immunization status?

Finding: Exclusive breastfeeding and complete basic immunization status have an effect in limiting the incidence of childhood pneumonia.

Meaning: While exclusive breastfeeding and complete basic immunization the Expanded Program on Immunization status are important factors for reducing the incidence of childhood pneumonia, indoor air pollution was also a significant risk factor.

\section{Introduction}

Acute respiratory infections (ARIs), especially pneumonia, remain major causes of morbidity and mortality among infants and toddlers in developed countries and in the developing world. ${ }^{1)}$ Globally, Streptococcus pneumonia is the most common pathogen causing community-acquired pneumonia. Pneumonia ranks among the 5 main causes of infant mortality. The high mortality rate caused by pneumonia makes it called 'The Forgotten Pandemic.' Based on 2015 data from United Nations Children's Fund, 100 children died each hour due to causes related to pneumonia, and in developing countries, death due to pneumonia occurs at a rate of $20 \%$ compared to a rate of $4 \%$ in developed countries. ${ }^{2,3)}$

Risk factors for pneumonia include malnutrition, indoor air pollution (air polluted by cigarette smoke of family members who smoke in the room of the house, the use of mosquito coils, and the use of firewood stoves for cooking in the house), high population density in the house, zinc deficiency, educational status of the mother and any previous experience she might have caring for children, presence of comorbidities, daycare, humidity, cold, lack of vitamin A in the diet, birth sequence, and low birth weight (LBW). ${ }^{4,5)}$ Factors considered to be of primary importance toward prevention of pneumonia are exclusive breastfeeding until the age of 6 months and completed basic

Corresponding author: Abdul Wahab, Dr, MPH. Department of Biostatistics, Epidemiology and Population Health Faculty of Medicine, Public Health and Nursing Universitas Gadjah Mada, Jl. Kaliurang Km 6.2 Pandega Padma I/ B06A, Yogyakarta, Indonesia 


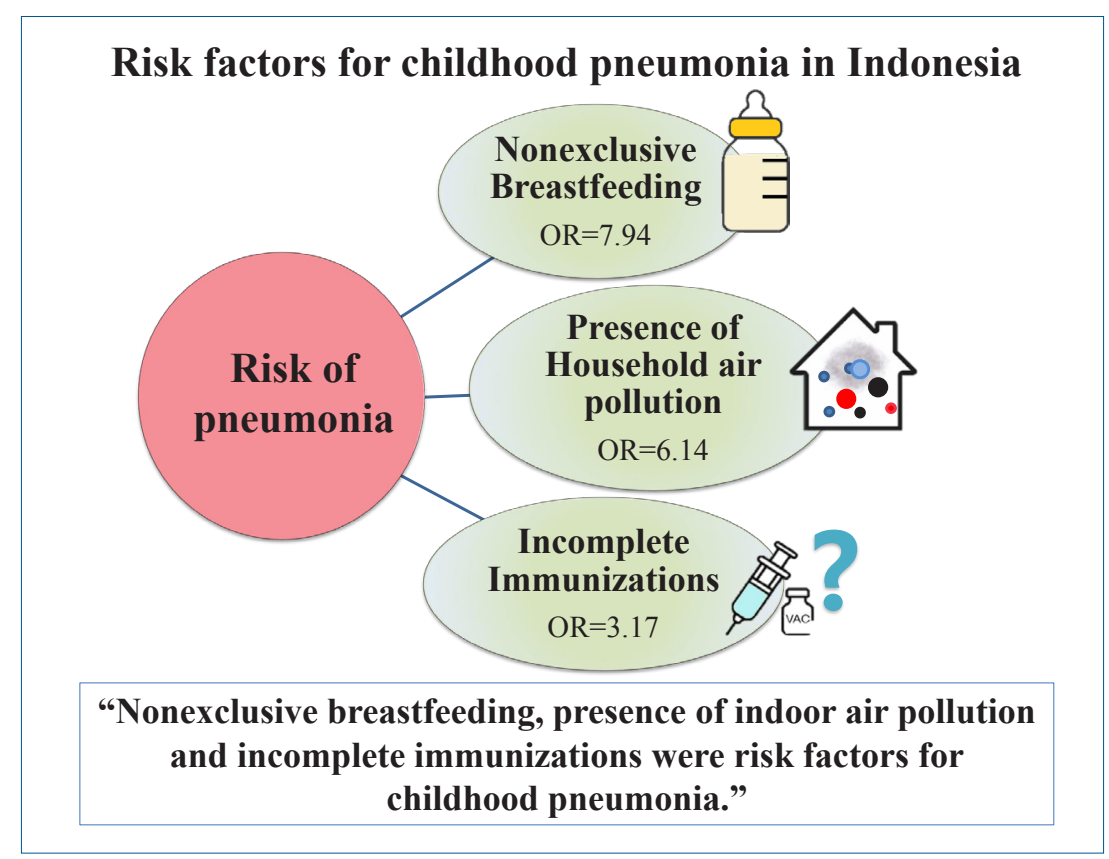

Graphical abstract

immunizations (Expanded Program on Immunization [EPI] coverage). ${ }^{6,7)}$

The total coverage of exclusive breastfeeding in Bojonegoro District, East Java Province, Indonesia is high exceeding the national coverage target rate, while the completeness basic immunization or the EPI coverage in Bojonegoro also has achieved the target for Universal Child Immunization. ${ }^{8,9)}$ Even with these public health achievements targets was good, the incidence of pneumonia remains high in this region and the number of new cases of pneumonia has still increased. Therefore, specific research is needed to identify risk factors associated with the high incidence of child pneumonia in Bojonegoro.

\section{Methods}

\section{Study design}

The research was designed as a case-control study in a rural area in the Bojonegoro Regency, East Java Province, Indonesia on March-April 2019. The case group was toddlers aged 10-59 months who were diagnosed with pneumonia, and the control group was healthy or sick toddlers (not diagnosed with pneumonia) of the same age who came for treatment at the health center where the research was carried out during the same period as the case group, on January 1, 2018 to January 31, 2019.

Exclusive breastfeeding (for the first 6 months of age) and the EPI (bacillus Calmette-Guerin, DPT-HB-HiB, Polio, and measles vaccines) as independent variables and the dependent variable was the incidence of child pneumonia. The external variables were age, sex, mother's education, nutritional status (stunting height-for-age $<-2.0 z$ score), (wasting body weight-for-height $<-2.0 z$ score), history of LBW, and indoor air pollution (air polluted by cigarette smoke of family members who smoke in the room of the house, the use of pesticides mosquito coils, and the use of firewood stoves for cooking in the house. The indicators are adjusted based on the standard results of the examination of The National Institute of Occupational Safety and Health related to indoor pollution sources. ${ }^{10)}$

The subjects were selected start from the age of 10 months to make it easier to identify and classify whether the child has received complete basic immunization, because the limit of the last basic immunization (measles vaccine is given in the age of 9-10 months) in the complete basic immunization (EPI) schedule in children less than 1 year. This approach, the research is clearly assessing the relationship of children who get complete basic immunizations (EPI) with the incidence of child pneumonia.

Secondary data collection in this study used nonprobability sampling technique by consecutive sampling, both groups for cases and controls. Samples were taken evenly in each primary health center work area with a high incidence rate of child pneumonia, in Dander District, Bojonegoro. The total samples are 176 subjects with 1:1 case comparison so that each group included 88 children. The selection of cases using medical record data, children diagnosed with pneumonia based on examination results and classified based on the Integrated Management of Childhood Illness (IMCI) approach. IMCI is a reference for health workers to classify the diagnosis of pneumonia in children aged 2 months to 5 years. Determination of the presence of rapid breathing is done by calculating the frequency of breaths using a sound timer. Classification of severe pneumonia in children if they show retraction of the lower chest wall or stridor. Children diagnosed with pneumonia were then selected according to the inclusion criteria as a case group. Then in terms of choosing a control group using seasonal matching techniques (sampling 
within the same time period) to keep off from the bias. For the example, if there is a child with pneumonia diagnosed on January 2019 as a case sample, then the control sample selection was healthy or sick child but not diagnosed with pneumonia, children with suffering from influenza, tonsillitis, or the common cold. If the number of children who appropriate the inclusion criteria as the control group is more than of them than the case group, then a random selection was carried out.

The researchers visited all respondent's homes for surveys and interviews. Besides using patient medical records, data were also obtained from interviews with toddler's parents using a valid questionnaire instrument. Then, the results of interviews were crosschecked with the book containing maternal and child health reports (the respondent's medical record book). The researchers also noted anthropometric examinations in children and the results of surveys of the respondents' home conditions which were conducted directly during the study. In the analyses, the bivariate analysis used chi-square tests, and multivariate analysis used with logistic regression. The ethical clearance for the study was approved by the Medical and Health Research Ethics Committee of Universitas Gadjah Mada (approval number: KE/ FK/0254/EC/2019). Written informed consent from parents and guardians of children were obtained after giving participants the detailed information about the study.

\section{Statistical analysis}

Statistical analysis was performed using Stata 13 (StataCorp LP., College Station, TX, USA). Bivariate analysis was used in 2-stage chi-square analysis. In the first stage was examined the relationship between the independent variables and the dependent variable; relative risk was determined in the second stage via calculation of the odds ratio (OR). Multivariate logistic regression was used to determine the relationship between the dependent variable and the independent variables when the latter were controlled by outside variables; confounding factors and/or modifier effects were also considered.

\section{Results}

\section{Participant characteristics}

The characteristics of all study participants are included in Table 1. As shown, most of the participants were within an age range of 1-3 years; we enrolled more females than males. The educational level of the mother was typically low. Most participants were not exclusively breastfed (63.64\%) while $60.23 \%$ had completed basic immunization. Of interest, most of the participants live in homes with substantial air pollution (70.45\%). Most of the participants had no history of stunted growth (height-for-age at $-2.0 z$ score) or a history of LBW. In terms of nutritional status (weight-for-height $z$ score, WHZ) most of the participants were within normal limits. Also, most participants report receipt of vitamin A tablets that have been completed according to their age, which according to the national guidelines are 2 supplements every year.

\section{Relationship of risk factors with child pneumonia}

The risk factors of child pneumonia are presented in Table 2. As shown, the odds of pneumonia in children who do not exclusive breastfed was 7.95 (OR, 7,95; confidence interval [CI], $3,52-17,94 ; P=0.000$ ) and the odds of pneumonia in children who do not receive complete basic immunization (EPI coverage) 4.47 (OR, 4,47; 95\% CI, 2,22-8,99; $P=0,000)$.

Then the external variables related to the incidence of pneumonia in children include nutritional status, wasting parameters, LBW history, and indoor air pollution. While the external variables not related to childhood pneumonia were age, sex, mother's educational status, and nutritional status (height-forage $z$ score, HAZ).

Multivariate analyzes were carried out to determine the impact

Table 1. Characteristics of the participants (10-59 months of age) from Regency Bojonegoro (2019)

\begin{tabular}{|c|c|}
\hline Variable & №. (\%) \\
\hline \multicolumn{2}{|l|}{ Age } \\
\hline $10 \mathrm{mo}$ to $<1 \mathrm{yr}$ & $5(2.84)$ \\
\hline $1-3 y r$ & $90(51.14)$ \\
\hline $4-5 \mathrm{yr}$ & $81(46.02)$ \\
\hline \multicolumn{2}{|l|}{ Sex } \\
\hline Male & $86(48.86)$ \\
\hline Female & $90(51.14)$ \\
\hline \multicolumn{2}{|c|}{ Mother's education } \\
\hline High & $7(3.98)$ \\
\hline Middle & $71(40.34)$ \\
\hline Low & $98(55.68)$ \\
\hline \multicolumn{2}{|l|}{ Breastfeeding } \\
\hline Exclusive & $64(36.36)$ \\
\hline Not exclusive & $112(63.64)$ \\
\hline \multicolumn{2}{|c|}{ Basic immunization } \\
\hline Complete & $106(60.23)$ \\
\hline Not complete & 70 (39.77) \\
\hline \multicolumn{2}{|c|}{ Household air pollution } \\
\hline Yes & $124(70.45)$ \\
\hline No & $52(29.55)$ \\
\hline \multicolumn{2}{|c|}{ Nutritional status (HA z score) } \\
\hline Stunted & $43(24.43)$ \\
\hline Not stunted & $133(75.57)$ \\
\hline \multicolumn{2}{|c|}{ Nutritional status (WH z score) } \\
\hline Normal & $152(86.36)$ \\
\hline Wasting & $24(13.64)$ \\
\hline \multicolumn{2}{|l|}{ LBW history } \\
\hline LBW & $23(13.07)$ \\
\hline No LBW & $153(86.93)$ \\
\hline \multicolumn{2}{|c|}{ Vitamin A supplementation ${ }^{a)}$} \\
\hline Complete & $132(75.00)$ \\
\hline Incomplete & $44(25.00)$ \\
\hline
\end{tabular}

HA, height-for-age; WH, weight-for-height; LBW, low birth weight.

a) Vitamin A supplementation: complete, get complete vitamin A (as much as 10 times) according to the schedule for 5 years; incomplete, if less than 10 times according to the specified schedule. 
Table 2. Relationship of risk factors with the incidence of pneumonia in children aged 10-59 months

\begin{tabular}{|c|c|c|c|c|c|c|}
\hline \multirow{2}{*}{ Variable } & \multicolumn{3}{|c|}{ Incidence of pneumonia } & \multirow{2}{*}{$\mathrm{OR}$} & \multirow{2}{*}{$(95 \% \mathrm{Cl})$} & \multirow{2}{*}{$P$ value } \\
\hline & Yes & No & Total & & & \\
\hline \multicolumn{7}{|l|}{ Age of child (mo) } \\
\hline $10-36$ & $51(57.95)$ & $44(50.00)$ & $95(53.98)$ & 1.37 & $(0.7-2.50)$ & 0.291 \\
\hline $37-59$ & $37(42.05)$ & $44(50.00)$ & $81(46.02)$ & 1.00 & & \\
\hline \multicolumn{7}{|l|}{ Sex } \\
\hline Male & $41(46.59)$ & $45(51.14)$ & $86(48.86)$ & 1.19 & $(0.6-2.17)$ & 0.547 \\
\hline Female & $47(53.41)$ & $43(48.86)$ & $90(51.14)$ & 1.00 & & \\
\hline \multicolumn{7}{|c|}{ Mother's education } \\
\hline Low & $53(60.23)$ & $45(51.14)$ & $98(55.68)$ & 1.14 & $(0.7-2.64)$ & 0.226 \\
\hline Middle-high & $35(39.77)$ & $43(48.86)$ & $78(44.32)$ & 1.00 & & \\
\hline \multicolumn{7}{|l|}{ Breastfeeding } \\
\hline Exclusive & $75(85.23)$ & 37 (42.05) & $112(63.64)$ & 7.95 & $(3.5-17.9)$ & 0.001 \\
\hline Not exclusive & $13(14.77)$ & $51(57.95)$ & $64(36.36)$ & 1.00 & & \\
\hline \multicolumn{7}{|c|}{ Basic immunization } \\
\hline Complete & $50(56.82)$ & $20(22.73)$ & $70(39.77)$ & 4.47 & $(2.2-8.99)$ & 0.001 \\
\hline Not complete & $38(43.18)$ & $68(77.27)$ & $106(60.23)$ & 1.00 & & \\
\hline \multicolumn{7}{|c|}{ Household air pollution } \\
\hline Yes & $78(88.64)$ & $46(52.27)$ & $124(70.45)$ & 7,12 & (3.03- 16.70) & 0.001 \\
\hline No & $10(11.36)$ & $42(47.73)$ & $52(29.55)$ & 1.00 & & \\
\hline \multicolumn{7}{|c|}{ Nutritional status (HA z score) } \\
\hline Stunted & $26(29.55)$ & $17(19.32)$ & $43(24.43)$ & 1.75 & $(0.8-3.55)$ & 0.115 \\
\hline Not stunted & $62(70.45)$ & $71(80.68)$ & $133(75.57)$ & 1.00 & & \\
\hline \multicolumn{7}{|c|}{ Nutritional Status (HW z score) } \\
\hline Wasting & $17(19.32)$ & $7(7.95)$ & $24(13.64)$ & 2.77 & $(1.0-7.17)$ & 0.028 \\
\hline Normal & $71(80.68)$ & $81(92.05)$ & $152(86.36)$ & 1.00 & & \\
\hline \multicolumn{7}{|l|}{ LBW history } \\
\hline LBW & $17(19.32)$ & $6(6.82)$ & $23(13.07)$ & 3.27 & $(1.1-8.92)$ & 0.014 \\
\hline Not LBW & $71(80.68)$ & $82(93.18)$ & $153(86.93)$ & 1.00 & & \\
\hline \multicolumn{7}{|c|}{ Vitamin A supplementation } \\
\hline Incomplete & $27(30.68)$ & $17(19.32)$ & $44(25)$ & 1.84 & $(0.9-3.74)$ & 0.08 \\
\hline Complete & $61(69.32)$ & $71(80.68)$ & $132(75)$ & 1.00 & & \\
\hline Total & $88(100)$ & $88(100)$ & $176(100)$ & & & \\
\hline
\end{tabular}

$\mathrm{OR}$, odds ratio; $\mathrm{Cl}$, confidence interval; $\mathrm{HA}$, height-for-age; HW, Height for weight; LBW, low birth weight.

Boldface indicates a statistically significant difference with $P<0.05$.

of each confounding effect and to select the best model. Selection of variables using advanced selection methods; variables found to be confounding variables are excluded from the modelling process.

The results of the modelling are shown in Table 3. Here we present model 1 as an unadjusted model (the combination of the 2 independent variables becomes the comparison model) and produce a crude OR value. Selection of the best model is done by looking at the largest pseudo $R^{2}$ value and the smallest Akaike's Information Criterion (AIC) value. We conclude that the best information comes from model 4 with a pseudo R2 value of 0.320 and the smallest AIC value (at 177.8).

Based on multivariate modelling, the results of the analysis explain that the contribution of exclusive breastfeeding (age 6 months), basic immunization status, indoor air pollution, history of LBW, and nutritional status (wasting parameters) can affect the incidence of pneumonia in children up to $32 \%$, and about $68 \%$ most likely caused by the influenced of other factors.

\section{Interaction and stratification test}

Interaction and stratification tests were performed in order to determine the specific impact of external variables on the relationship between breastfeeding and vaccination and the incidence of child pneumonia among participants in our study. By this method, we identified the sex variable as the modifier effect as having a significant relationship with the exclusive breastfeeding with respect to the incidence of childhood pneumonia.

The results of stratification for exclusive breastfeeding and the incidence of childhood pneumonia based on the sex of child are shown in Table 4. We identified an initial OR of 0.083 in the bivariate analysis which increased to 3.94 in boys and 17.4 in girls. As such, we can conclude that the likelihood of pneumonia in an infant or toddler (10-59 months) will be greater among females who are not exclusively breastfed. 
Table 3. Models resulting from the multivariable analysis

\begin{tabular}{|c|c|c|c|c|}
\hline Variable & Model 1 & Model 2 & Model 3 & Model 4 \\
\hline \multicolumn{5}{|l|}{ Breastfeeding } \\
\hline Exclusive & 1 & 1 & 1 & 1 \\
\hline Not exclusive & $6.95(3.272-14.76)$ & $7.043(3.156-15.72)$ & 7.528 (3.299-17.18) & 7.937 (3.407-18.49) \\
\hline \multicolumn{5}{|c|}{ Basic immunization } \\
\hline Complete & 1 & 1 & 1 & 1 \\
\hline Not complete & $3.732(1.828-7.618)$ & $3.324(1.557-7.096)$ & $3.325(1.5433-7.165)$ & $3.19(1.479-7.006)$ \\
\hline \multicolumn{5}{|c|}{ Household air pollution } \\
\hline Yes & - & $6.471(2.692-15.56)$ & $6.208(2.565-15.02)$ & $6.141(2.515-14.99)$ \\
\hline No & - & 1 & 1 & 1 \\
\hline \multicolumn{5}{|l|}{ History of LBW } \\
\hline LBW & - & - & 3.045 (0.937-9.893) & $2.920(0.885-9.641)$ \\
\hline Not LBW & - & - & 1 & - \\
\hline \multicolumn{5}{|c|}{ Nutritional status (WH z score) } \\
\hline Wasting & - & - & - & $2.927(0.906-9.452)$ \\
\hline Normal & - & - & - & 1 \\
\hline Number & 176 & 176 & 176 & 176 \\
\hline Pseudo $R^{2}$ & 0.209 & 0.291 & 0.306 & 0.320 \\
\hline AIC & 198.9 & 181.0 & 179.3 & 177.8 \\
\hline
\end{tabular}

Values are presented as odds ratio (95\% confidence interval).

LBW, low birth weight; WH, weight-for-height; AIC, Akaike's Information Criterion.

Boldface indicates a statistically significant difference with $P<0.001$.

Table 4. Stratification: exclusive breastfeeding and the incidence of pneumonia based on sex of child (aged 10-59 months)

\begin{tabular}{lccc}
\hline Variable & OR & $95 \% \mathrm{Cl}$ & $P$ value \\
\hline Breastfeeding + male sex & & & \\
Exclusive breastfeeding + male sex & 1 & - & - \\
$\quad$ Not exclusive breastfeeding + male sex & 3.9 & $(1.51-10.21)$ & $\mathbf{0 . 0 0 4}$ \\
Breastfeeding + female sex & & & \\
Exclusive breastfeeding + female sex & 1 & - & - \\
Not exclusive breastfeeding + female sex & 17.4 & $(5.77-51.97)$ & $\mathbf{0 . 0 0 1}$ \\
\hline
\end{tabular}

$\mathrm{OR}$, odds ratio; $\mathrm{Cl}$, confidence interval.

Boldface indicates a statistically significant difference with $P<0.05$.

\section{Discussion}

Children who were not breastfed exclusively until 6 months of age had a nearly 8 -fold higher chance of contracting pneumonia than did children who were breastfed exclusively. Only 36\% of the children in our cohort were breastfed exclusively; this is still quite far from the national target of $80 \%$. Breast milk contains nutrients, hormones, and growth factors as well as elements that prevent allergies and inflammation and promote immunity. Recent research in the United States and the United Kingdom showed children who are breastfed exclusively become ill much less frequently than children who are not breastfed. ${ }^{11,12)}$

Research from the group of Lamberti et al. ${ }^{13)}$ showed children who are not breastfed optimally or exclusively have a higher risk for morbidity and mortality secondary to pneumonia at all age levels. Pneumonia mortality was highest among children who were not breastfed exclusively, notably in the age range of $0-5$ months. Breast milk contains colostrum, which is $\sim 16 \%$ protein and contains immunoglobulin A, lactoferrin, and white blood cells that contribute to the prevention of infections. ${ }^{14)}$ Similar research featuring a cohort from Brazil found that children who were not breastfed were 17 times more likely to be hospitalized with pneumonia than were breastfed children; as such, the study concluded that breastfeeding could protect children from the most severe forms of pneumonia, especially in the first month of life. ${ }^{15)}$

Most of the participants in our study have received complete basic immunization (60\%), although this number also does not meet the national target. We found here that children with incomplete basic immunization were nearly 5 times more likely to contract pneumonia than children whose basic immunizations were complete. Both baseline and booster vaccines serve to prevent numerous childhood illnesses; this is among the most cost-effective solutions to prevent childhood death from pneumonia. ${ }^{16,17)}$ This finding supports the conclusions of Damanik et al. ${ }^{18)}$ which indicated that children between the ages of 12-24 months who suffer from ARIs are 3.8 times more likely to be lacking basic immunizations compared to children who do not suffer from ARIs including pneumonia. Likewise, Madhi et al. ${ }^{7}$ also reported that vaccines have played an important role in the prevention of pneumonia. These strategies have included maximizing the number of children who receive routine diphtheria, pertussis and tetanus immunization and the measles vaccines, coupled with measles booster; this has resulted in a rapid reduction in child mortality in low-income countries, especially in Africa. It is interesting to note that basic immunization correlates with protection against pneumonia despite the fact that the pneumococcal conjugate vaccine has not yet been included in this vaccine regimen.

We found no significant relationship between the age of 
the toddler and the incidence of pneumonia among our study participants. This may be a consequence of the fact that the age of the participants varied between the 2 groups. Most of the children in the case group were $>1$ year old. Nonetheless, this finding is consistent with those reported by Suwarto et al. ${ }^{15}$ ) which also revealed no relationship between the age and the incidence of pneumonia in children under 5 years $(P=0.642)$. Muhe et al. ${ }^{19)}$ and Greenberg et al. ${ }^{20)}$ came to similar conclusions. We also found no relationship between sex and the incidence of pneumonia among children in our cohort, an observation that may relate to different proportions of males and females enrolled in the study. This is notable given that some studies have reported that the incidence of ARIs in boys under 5 years of age is higher than that of girls. ${ }^{21)}$ However, the studies of Greenberg et al. ${ }^{20)}$ and Sukamawa et al. ${ }^{22)}$ also found no specific relationship between sex and the incidence of child pneumonia $(P=0.09)$ as did Nieminen et al. ${ }^{23)}$ in a study focused on toddlers.

The results of the interaction and stratification tests revealed significant association sex with exclusive breastfeeding against the incidence of child pneumonia, which means that, among infants and toddlers who are not exclusively breastfed, girls are more likely to develop pneumonia than boys. Among the reasons that might explain this, girls in Bojonegoro are kept inside the home more than boys and they may be exposed more often and more intensely to indoor air pollution, particularly if one or both parents smoke, used of mosquito coils, and use of wood stoves for cooking. But with the advances in technology (playing with gadgets or other new toys) and current facilities, it certainly affects the habits of children to play more often in the house both boys and girls. So, if more girls are found or at risk of pneumonia, it is also likely that this is more due to exposure to air contaminated with pollution in the home such as cigarette smoke, a child's personal hygiene patterns that are lacking or low intake of nutrients that affect their immunity.

There was no relationship found between the educational status of the mothers and the incidence of pneumonia in children in our study. The study of Budiati came to similar conclusions. According to Machmud, one might anticipate higher morbidity and mortality among the less well-educated mothers because the children may not be receiving adequate food or appropriate health care. ${ }^{24)}$ Fatmi and White ${ }^{25)}$ identified no significant relationship between the education of parents with the incidence of pneumonia in children. The study of Tiewsoh et al. ${ }^{26}$ reached much the same conclusions. Nonetheless, these findings are in contrast to the results presented by Nirmolia et al. ${ }^{27)}$ which showed that lack of maternal education is significantly correlated with the incidence of pneumonia. Additionally, the use of health care facilities was directly related to knowledge regarding pneumonia symptoms. As such, we can conclude that even mothers with relatively low levels of formal education might be educated in the signs and symptoms of pneumonia, so that proper steps might be taken toward seeking treatment for pneumonia as necessary.

Furthermore, our study revealed no significant relationship between nutritional status (HAZ) and the incidence of child pneumonia. This result might relate to the fact that the participants in our study had mostly normal growth, although it is of course not possible to know past nutritional status for certain; height was measured at the start of the study and most likely reflected nutritional status when pneumonia occurred. Fatmi and White ${ }^{25)}$. reported that the impact of nutritionally-related short stature on the growth and development of lung function is not yet known. ${ }^{25)}$ However, stunted growth did increase the risk of treatment failure and is associated with longer recovery in children with pneumonia.

The relationship between nutritional status (WHZ) and the incidence of pneumonia in in our cohort is in line with the research of Fonseca et al. ${ }^{28)}$ which reported that malnutrition is the most important risk factor for pneumonia in childhood. Nurnajiah et al. ${ }^{29)}$ identified a similar significant relationship between the nutritional status of children (13-59 months) with pneumonia who were hospitalized in Padang. These findings are also similar to those of the Caulfield et al..$^{30)}$ which indicated that malnutrition in childhood contributes significantly to the global burden of disease, specifically that $52.3 \%$ of child deaths due to pneumonia are directly related to malnutrition.

Children with a history of LBW had over a 3-fold higher chance of contracting pneumonia than did children without a history of LBW. This finding corresponds to those of Hadisuwarno et al. ${ }^{31)}$ which showed that $\mathrm{LBW}$ was associated with an increased the risk of pneumonia $(P=0.005)$. Nutritional factors may have primarily indirect effects but their long-term impact clearly plays an important role as a risk factor for pneumonia.

Children who live with high levels of indoor air pollution have more than a 7 -fold higher risk of contracting pneumonia than do infants and toddlers who live in homes without this condition. Most of the indoor air pollution was directly attributed to family members who were smoking cigarettes inside the house. Smoking inside the house, and also the use of mosquito coils and/or firewood stoves will have a direct impact on the quality of inhaled air. Mukono et al. ${ }^{10)}$ defined 5 sources of indoor pollution based on the results of an examination by The National Institute of Occupational Safety and Health; these include cigarette smoke, pesticides, and kitchen fumes. Greenberg et al. ${ }^{20)}$ showed that children under 5 years of age who are exposed to secondhand smoke are at a higher risk of pneumonia than children who are not exposed to cigarette smoke $(P=0.016)$. Cigarette smoke in the home is also associated with bacterial infections including Neisseria meningitidis, Streptococcus pneumoniae, and Haemophilus influenza which are the most common bacterial pathogens which cause respiratory infections.

The use of mosquito coils inside the house remains prevalent, and these can be found even in bedrooms where children are sleeping. Mosquito coils also contain chemicals that are harmful to the respiratory system. Research from the group of Zhang et al. ${ }^{32)}$ showed that exposure to smoke and the by-products of burned mosquitoes can cause significant acute and chronic health risks. The use of a single coil in the home results in 
release of the same amount of pollutants as 75-137 cigarettes, and produce smoke which contains toxic carbonyl compounds including formaldehyde and acetaldehyde which are respiratory tract irritants as well as carcinogens.

There are many study participants in families that use firewood for cooking; this is commonplace in rural areas of Indonesia. Particles from the combustion of biofuels such as fuelwood, charcoal, agricultural residues, and livestock manure have been implicated as agents of respiratory disease in several developing countries. ${ }^{33,34)}$ The Balmes study also stated that the use of furnaces/firewood was significantly associated with pneumonia, and provided clear evidence for the increased risk for more severe pneumonia due to disruption of the respiratory defense mechanisms. ${ }^{16}$ )

In conclusion, this research emphasizes the importance of exclusive breastfeeding in the first 6 months of life as well as complete basic immunizations for preventing childhood pneumonia, particularly in areas of high prevalence. Nutritional status (WHZ), history of LBW, and indoor air pollution are all significantly associated with pneumonia in children in the 10to 59-month age cohort; there were no confounding external variables to report. Sex of the child modified the relationship between exclusive breastfeeding and the incidence of child pneumonia; a female child who is not breastfed exclusively has a higher risk for developing pneumonia than dose her male counterpart.

\section{Footnotes}

Conflicts of interest : No potential conflict of interest relevant to this article was reported.

Acknowledgments : We are grateful to staff of Klinik Bahasa Faculty of Medicine and the Team of Language Editing Universitas Gadjah Mada for proof reading assistance.

ORCID:

Vivi Ninda Sutriana (1) https://orcid.org/0000-0003-1070-2316 Mei Neni Sitaresmi @ https://orcid.org/0000-0002-8620-712X Abdul Wahab @ https://orcid.org/0000-0003-3198-8851

\section{References}

1. Kementerian Kesehatan Republik Indonesia. Pedoman pencegahan dan pengendalian infeksi saluran pernapasan akut. Jakarta (Indonesia): Departemen Kesehatan Republik Indonesia, 2016

2. Sugihartono S, Rahmatullah P, Nurjazuli N. Analisis faktor risiko kejadian pneumonia pada balita di wilayah kerja Puskesmas Sidorejo Kota Pagar Alam. J Kesehat Lingkung Indones 2012;11:82-6.

3. Hug L, Sharrow D, You D. Levels \& trends in child mortality: report 2017. Estimates developed by the UN Inter-agency Group for Child Mortality Estimation. New York: UNICEF, 2017.

4. Hartati S. Analisis faktor risiko yang berhubungan dengan kejadian pneumonia pada anak balita Di RSUD Pasar Rebo. Jakarta (Indonesia): Uiniversitas Indonesia. Tesis; 2011.
5. Fekadu GA, Terefe MW, Alemie GA. Prevalence of pneumonia among under-five children in Este Town and the surrounding rural Kebeles, Northwest Ethiopia: a community based cross sectional study. Sci J Pub Health 2014;2:150-5.

6. César JA, Victora CG, Barros FC, Santos IS, Flores JA. Impact of breast feeding on admission for pneumonia during postneonatal period in Brazil: nested case-control study. BMJ 1999;318:1316-20.

7. Madhi SA, Levine OS, Hajjeh R, Mansoor OD, Cherian T. Vaccines to prevent pneumonia and improve child survival. Bull World Health Org 2008;86:365-72.

8. Dinas Kesehatan Provinsi Jawa Timur. Profil Kesehatan Provinsi Jawa Timur Tahun 2016. Surabaya (Indonesia): Dinas Kesehatan Provinsi Jawa Timur, 2017.

9. Dinas Kesehatan Kabupaten Bojonegoro. Profil Kesehatan Kabupaten Bojonegoro Tahun 2016. Bojonegoro (Indonesia): Dinas Kesehatan Kabupaten Bojonegoro, Jawa Timur, 2017.

10. Mukono J, Prasasti CI, Sudarmaji S. Pengaruh kualitas udara dalam ruangan Ber-AC terhadap gangguan kesehatan. J Kesehat Lingkung Unair 2005;1:160-9

11. Hastuti P, Wijayanti IT. Analisis Deskriptif Faktor yang Mempengaruhi Pengeluaran ASI pada Ibu Nifas di Desa Sumber Kecamatan Sumber Kabupaten Rembang. Proceeding 6th University Research Colloquium 2017. URECOL 2017:223-32.

12. Chantry CJ, Howard CR, Auinger P. Full breastfeeding duration and associated decrease in respiratory tract infection in US children. Pediatrics 2006;117:425-32.

13. Lamberti LM, Zakarija-Grković I, Fischer Walker CL, Theodoratou E, Nair H, Campbell H, et al. Breastfeeding for reducing the risk of pneumonia morbidity and mortality in children under two: a systematic literature review and meta-analysis. BMC Public Health 2013;13 Suppl 3(Suppl3):S18.

14. Fikri BA. Analisis Faktor risiko pemberian asi dan ventilasi kamar terhadap kejadian pneumonia balita. Indo J Pub Health 2016;11:14-27.

15. Suwarto SU, Fadlyana E, Kartasasmita C. Hubungan Kadar Prokalsitonin dan Kultur Bakteri dengan Tingkat Keparahan Pneumonia pada Anak. Sari Pediatri 2016;17:261-6.

16. Balmes JR. Household air pollution from domestic combustion of solid fuels and health. J Allerg Clin Immunol 2019;143:1979-87.

17. Palfrey JS, Brei TJ. Children's health care providers and health care quality measurement. Acad Pediatr 11(3 Suppl):S87-8.

18. Damanik P, Siregar MA, Aritonang EY. Hubungan Status Gizi, Pemberian ASI. Eksklusif, Status Imunisasi Dasar dengan Kejadian Infeksi Saluran Pernapasan Akut (ISPA) pada Anak Usia 12-24 Bulan di Wilayah Kerja Puskesmas Glugur Darat Kota Medan. Gizi, Kesehatan Reproduksi dan Epidemiologi 2014;1:1-7.

19. Muhe L, Lulseged S, Mason KE, Simoes EA. Case-control study of the role of nutritional rickets in the risk of developing pneumonia in Ethiopian children. Lancet 1997;349:1801-4.

20. Greenberg D, Givon-Lavi N, Broides A, Blancovich I, Peled N, Dagan $\mathrm{R}$. The contribution of smoking and exposure to tobacco smoke to Streptococcus pneumoniae and Haemophilus influenzae carriage in children and their mothers. Clin Infect Dis 2006;42:897-903.

21. Tanjung WW, Batubara NS, Siregar PK. Faktor-Faktor Risiko Yang Berpengaruh Terhadap Kejadian Pneumonia Pada Balita Di Rumah Sakit Tentara Nasional Indonesia Angkatan Darat (Tni-Ad) Kota Padangsidim. puan. Indo Health Sci J 2017;2:1-10.

22. Sukamawa AAA, Sulistyorini L, Keman S. Determinan sanitasi rumah dan sosial ekonomi keluarga terhadap kejadian ISPA pada anak balita serta manajemen penanggulangannya di Puskesmas. Jurnal Kesehatan Lingkungan 2006;3:49-58.

23. Nieminen H, Rinta-Kokko H, Jokinen J, Puumalainen T, Moreira M, Borys $\mathrm{D}$, et al. Effectiveness of the 10-valent pneumococcal conjugate vaccine among girls, boys, preterm and low-birth-weight infants - results from a randomized, double-blind vaccine trial. Vaccine 2019;37:371521.

24. Budiati E. Kondisi Rumah dan Pencemaran Udara Dalam Rumah Sebagai Faktor Risiko Kejadian Pneumonia Balita. YARSI Med J 2016;20:87- 
101.

25. Fatmi Z, White F. A comparison of 'cough and cold'and pneumonia: risk factors for pneumonia in children under 5 years revisited. Int $J$ Infect Dis 2002;6:294-301.

26. Tiewsoh K, Lodha R, Pandey RM, Broor S, Kalaivani M, Kabra SK. Factors determining the outcome of children hospitalized with severe pneumonia. BMC Pediatr 2009;9:15.

27. Nirmolia N, Mahanta TG, Boruah M, Rasaily R, Kotoky RP, Bora R. Prevalence and risk factors of pneumonia in under five children living in slums of Dibrugarh town. Clin Epidemiol Global Health 2018;6:1-4.

28. Fonseca W, Kirkwood BR, Victora CG, Fuchs S, Flores J, Misago C. Risk factors for childhood pneumonia among the urban poor in Fortaleza, Brazil: a case--control study. Bull World Health Org 1996;74:199.

29. Nurnajiah M, Rusdi R, Desmawati D. Hubungan Status Gizi dengan Derajat Pneumonia pada Balita di RS. Dr. M. Djamil Padang. Jurnal Kesehatan Andalas 2016;5:250-5.

30. Caulfield LE, de Onis M, Blössner M, Black RE. Undernutrition as an underlying cause of child deaths associated with diarrhea, pneumonia, malaria, and measles. Am J Clin Nutr 2004;80:193-8.
31. Hadisuwarno W, Setyoningrum RA, Umiastuti P. Host factors related to pneumonia in children under 5 years of age. Paediatr Indo 2015;55:24851.

32. Zhang L, Jiang Z, Tong J, Wang Z, Han Z, Zhang J. Using charcoal as base material reduces mosquito coil emissions of toxins. Indoor Air 2010;20:176-84.

33. Ezzati M, Kammen DM. Indoor air pollution from biomass combustion and acute respiratory infections in Kenya: an exposure-response study. Lancet 2001;358:619-24.

34. Ezzati M, Kammen DM. Quantifying the effects of exposure to indoor air pollution from biomass combustion on acute respiratory infections in developing countries. Environ Health Perspect 2001;109:481-8.

How to cite this article: Sutriana VN, Sitaresmi MN, Wahab A. Risk factors for childhood pneumonia: a case-control study in a high prevalence area in Indonesia. Clin Exp Pediatr 2021;64:588-95. https://doi.org/10.3345/cep.2020.00339 